\title{
The legal nature of pre-insolvency proceedings under Russian and European law
}

\author{
L. Mastilovich \\ St. Petersburg State University, \\ 7-9, Universitetskaya nab., St. Petersburg, 199034, Russian Federation
}

For citation: Mastilovich, Larisa. 2021. “The legal nature of pre-insolvency proceedings under Russian and European law”. Vestnik of Saint Petersburg University. Law 2: 441-454.

https://doi.org/10.21638/spbu14.2021.212

The article provides a critical analysis of bankruptcy prevention procedures in the context of interactions between the principle of self-regulation (interaction between free legal will of creditors and the debtor) and the principle "cross-class cram-down" (the right of a court to prevail over the principle of self-regulation). The judicial authority, within the framework of European preventive restructuring law, has the absolute right to discretionally decide on any issue if it is approved by the debtor (freedom of entrepreneurial activity is guaranteed to every solvent debtor). Interference in the business of the solvent and insolvent debtor by judicial authority is not allowed in any other procedures including traditional insolvency court procedures (the majority of creditors are empowered to make decisions). In all legal orders, the traditional insolvency court procedures prioritize the principle of "majority of creditors" to the principle of self-regulation in contrast to European preventive restructuring procedures, where the principle of self-regulation dominates. Therefore, European preventive restructuring cannot be unambiguously attributed to either a civil law legal nature or a bankruptcy law legal nature. In Russia pre-insolvency procedures represent only the civil law legal nature during all procedure. The author introduces new pre-bankruptcy terms: "normative legal collectivity" - mandatory distribution of consequences to all parties, "actual collectivity" - the voluntary consent of all creditors in a particular case and "regulatory actual collectivity" - the requirements for voluntary consent of all creditors. The final result of the European preventive restructuring procedure is unknown until the very end (the same for traditional insolvency court procedures), while according to Art. 31 of the Bankruptcy Law Act of the Russian Federation, the result is fully known from the beginning where it works according to the principle: "either everything and immediately, or nothing".

Keywords: insolvency, legal nature, reorganization, pre-insolvency proceedings, bankruptcy prevention, preventive restructuring.

\section{Introduction}

The role of insolvency legislation is to assess not only the risks in case of failure of the bankruptcy prevention, but also the benefits in case of success. The outcome of liquidation insolvency procedures is always predictable (liquidation of the debtor), in contrast to the bankruptcy prevention procedures where the only predictable outcome is the

* The reported study was funded by the RFBR, project No. 19-311-90063 "Debt restructuring as a measure of bankruptcy prevention under European law".

(c) St. Petersburg State University, 2021 
impossibility of liquidation. Normative regulation should not be so strict because the result of bankruptcy prevention procedure depends on many factors. Hence, the judicial authority should have the right to reduce rights of dissenting creditors if it is assessed that potential benefits of a successful outcome outweigh the harm in the event of failure. The successful result of bankruptcy prevention provides a "win-win" situation for all subjects, but there is no guarantee of the related achievement (De Weijs, Baltjes 2018, 224-226, 230-236). In as much as the judicial authority decides at the moment of the approval of the plan, based on the predictions of the future financial situation of the debtor, there is a possibility that this prediction has only a high probability of occurrence and it cannot be exact (Garašić 2017, 134). Only bankruptcy legislation is capable of making economic forecasts and based on these predictions provide regulation in order to establish a legal basis for limiting individual creditors' rights in favor of collective goals of all subjects. A solvent debtor, as an individual subject, cannot reliably determine the economic moment when preventive restructuring should be initiated or predetermine its result, although the participation of the legislator and judicial authority increases the chances of a correct prediction. This cannot be determined with absolute certainty by either the legislator or the judicial authority and, respectively, this is the reason why it is impossible to provide liability for the debtor if the procedure was not initiated when necessary or initiating it when there was no need.

Each legal order has its own legal basis for entering bankruptcy proceedings. The difference is even greater in terms of regulating accessibility of entering the bankruptcy prevention procedure: in some it is possible only for solvent debtors ${ }^{1}$, in others it is possible only for already insolvent debtors ${ }^{2}$, and in others at both stages. An indispensable requirement of both European and Russian bankruptcy prevention is the voluntary consent of the debtor. The debtor's right to initiate preventive restructuring according to European regulation depends on whether it is insolvent (debtor has no rights) or solvent (has the right to initiate). Directive 1023/2019 is characterized by voluntariness in relation to the debtor's initiative and coercion in relation to creditors, which is compensated by the protection of their "best-interest-of-creditors test" within preventive restructuring regulation ensures a wider range of persons' interests. In the absence of such a guarantee, the traditional pre-insolvency law approches civil law. It is not only the debtor who decides on preventive restructuring, but also the creditors and the judicial authority. The element of civil law is observed only in relation to the debtor (the requirement to obtain his voluntary consent), but in relation to creditors there is a bankruptcy element (the will of the majority of creditors extends to a minority of

${ }^{1}$ Directive (EU) 1023/2019 of the European Parliament and of the Council of 20 June 2019 on preventive restructuring frameworks, on discharge of debt and disqualifications, and on measures to increase the efficiency of procedures concerning restructuring, insolvency and discharge of debt, and amending Directive (EU) 2017/1132 (Directive on restructuring and insolvency). OJ L 172. Accessed November 27, 2020. https://eur-lex.europa.eu/legal-content/EN/TXT/?uri=celex:32019L1023. (Hereafter - Directive $1023 / 2019$.)

2 Chapter 2 Articles 30 and 31 of the Russian bankruptcy Act. Accessed October 19, 2020. http:// www.consultant.ru/document/cons_doc_LAW_39331.

3 According to Article 2 of Directive (EU) 1023/2019, the "best-interest-of-creditors test" means a test that is satisfied if no dissenting creditor would be worse off under a restructuring plan than such a creditor would be if the normal ranking of liquidation priorities under national law were applied, either in the event of liquidation, whether piecemeal or by sale as a going concern, or in the event of the next-best-alternative scenario if the restructuring plan were not confirmed. 
creditors and the judicial authority can act against the will of the creditors). Since the interests of dissenting creditors are also taken into account, there are veiled elements of civil law regulation (it is possible against creditors' will, but not against their interests). Taking into account that, within the European framework of preventive restructuring, the judicial authority can approve a preventive restructuring plan without the consent of the majority of creditors (classes), it can be stated that this procedure is more potentially collective in terms of compulsory distribution of legal consequences than traditional insolvency proceedings. Within the framework of the regulation of preventive restructuring, the debtor has the right to do what is reasonable and fair in relation to all the interested parties in the procedure. Bankruptcy and pre-bankruptcy regulation is not based on corporate regulation because the debtor has no right to independently determine the goals and counterparties, which are limited by law and the judicial authority. The only purpose of bankruptcy prevention procedures is strictly defined - its prevention, while the primary purpose of civil contracts is to generate profits and benefits and the parties have the freedom to determine any conditions, goals and persons entering into the contract while bankruptcy prevention does not allow for any alterations. Such a collective limitation of legal will and the predetermination of goals and objectives is not observed in the framework of contractual regulation.

\section{Basic research}

\subsection{European Directive on preventive restructuring 1023/2019}

As a general rule, the approval of a preventive restructuring requires the consent of a majority of creditors and debtor, and the legal consequences of the approved preventive restructuring plan applies to all creditors despite the fact that all initial legal relationships between the debtor and each of its creditors differ from each other. In accordance with Art. 11 and 14 of Directive 1023/2019, the judicial authority has the right to approve a plan of preventive restructuring even without the consent of the majority of creditors and it has the right not to approve the plan if the necessary consent of the majority of creditors is obtained. This means that the debtor can bind the dissenting creditors through the court, but the creditors cannot bind the dissenting debtor. Creditors are indirectly obliged to argue and participate in negotiations of preventive restructuring, but they cannot oblige the debtor to act in good faith and provide reliable information. Under European regulation, the judicial authority has a legal right to overcome the criterion of the majority of creditors, which means that pre-bankruptcy regulation is "stronger" and different than bankruptcy. If the consent of the majority of creditors is not needed, we can automatically say that neither the consent of all creditors is needed (consent of all parties is needed in civil law regulation). This means that preventive restructuring does not have the nature of either bankruptcy or contract law regulation.

Preventive restructuring, as a procedure, is divided into two phases: 1) negotiations between the debtor and creditors that are governed by civil law legal nature because neither the judicial authority nor the debtor can restrict the legal will of creditors; 2 ) approval and implementation on preventive restructuring plan. The debtor has a right to independently initiate negotiations after which the debtor has the possibility of binding the legal will of dissenting creditors by the judicial authority. This characterizes the bankruptcy 
law's legal nature. Furthermore, bankruptcy legal nature (non-civil law legal nature) is evident in Article 7 of paragraph 4 and in the preamble of Directive 1023/2019 (paragraph 40) which regulates that from the moment of the commencement of negotiations on preventive restructuring, creditors cannot "terminate or in any other way modify the main provisions of their already existing contracts". Ipso facto clauses provide an opportunity to creditors to terminate the contract not only when the traditional insolvency procedure has been initiated, but also earlier when participants have applied. According to Directive 1023/2019, creditors cannot put out of force ipso facto clauses that are eventually contained in theirs contracts between the debtor and each of the creditors. Otherwise, some creditors would use their right and terminate the contract with the debtor. It would harm not only the rescue of the debtor, but also be unfair to other creditors who do not terminate their contracts in order to help the recovery of the debtor. Such unfair regulation would create inequality between creditors at the pre-insolvency stage. The need to restore the debtor should depend not only on the prospects for retaining the debtor, but also on what costs may be caused to creditors from ensuring an adversarial nature of this procedure. The reason of disagreement by creditors to support the debtor's proposed plan on preventive restructuring may not be because the plan is not perspective enough, but they might have planned to terminate the legal and economic relations even before the debtor's proposal (e. g., it is more profitable for creditors to look for a new counterparty). These market considerations cannot be subject to legal scrutiny because they relate to the bilateral "internal and secretive" relationship of each specific creditor and debtor (characteristic of civil law). To overcome such civil law rights of each creditor, Directive $1023 / 2019$ prohibits creditors from initiating enforcement procedures from the beginning of negotiations throughout the implementation of preventive restructuring and ensures the right to judicial authority to overcome the legal will of dissenting creditors after having checked the criteria of a "best-interest-of-creditors test". Since at the end of all preventive restructuring, all the restrictions of the creditors end and the question appears why is the judicial authority empowered with assessing economic reasons of creditors refusing to support the preventive restructuring plan (it is important to keep in mind that the creditor will have the right to terminate the economic relations with the debtor again according to civil law rules)? One possible answer is that the priority is to rescue the debtor who is in financial difficulties despite the creditors' principle of the "best-interest-of-creditors test". It should be noted that the reason why creditors support preventive restructuring is that they expect that this amount will still be higher than they are guaranteed by the "bestinterest-of-creditors test' (the creditor makes his own choice based on civil law, but with the expectation of bankruptcy regulation). Bankruptcy regulation is necessary to ensure the "best-interest-of-creditors test".

Some authors believe that the "conclusion of a preventive restructuring plan automatically changes all previous legal relations between the debtor and individual creditors" (Eidenmüller 2018, 66), which gives the procedure the legal nature of civil law. On the other hand, the principle of "best-interest-of-creditors test" guarantees creditors minimum amounts of claims according to bankruptcy law. The bankruptcy guarantee is firmly interdependent on the same previous initial legal contracts between the debtor and each of the debtor's creditors and arises from them. Therefore, it cannot be characterized simply as bankruptcy law regulation. On the other hand, there is no inherent element of civil law regulation - the independence of legal relations (the preventive restructuring plan 
could not have been present if there were no numerous initial legal relations of the debtor with each of the creditors). The preventive restructuring plan does not change these legal relationships, but rather postpones their implementation. If the economic result of the procedure becomes a failure, all these initial legal relationships will remain unchanged as they are in their original form (before the failure of the plan preventive restructuring, it was uniformly applied to all legal relationships of creditors with the debtor, but after failure, it will no longer have an effect on the initial legal relationship).

The court takes into account creditors' arguments when making decisions based on the principle "cross-class cram-down" based not on a "quantitative" but on a "qualitative" approach which is not typical for traditional bankruptcy proceedings. This ensures more stable decisions that are not subject to creditors' complaints who would have posed dispute if the creditors were empowered with the final decision-making process instead of the judicial authority. The principle of "cross-class cram-down" is applied only in cases where it is necessary to prevent bad faith behaviour of specific creditors or classes in order to protect the common interests of all creditors (De Weijs, Baltjes, 2018, 232-236). The court can use this principle when it benefits creditors as a group (Tollenaar 2017, 71). All the creditors' claims must be evaluated as a whole and the losses involved shared out fairly (Kutufà 2018, 76). Directive 1023/2019 recommends the least possible judicial intervention and involvement (Eidenmüller 2018, 59, 67, 69, 70). Despite the fact that the protection of good faith in civil law already exists, in European pre-bankruptcy regulation it gets a higher standard. A debtor may fully disclose his financial situation to creditors during negotiations (a bona fide debtor) or partially (a non bona fide debtor by submitting only the information that indicates good financial prospects, which encourages creditors to agree to the procedure based on incorrect information). When the majority of creditors agree with the preventive restructuring plan, the good faith of the debtor is presumed and is not subject to verification by the judicial authority (self-regulation principle). A non bona fide debtor will not be able to extend his legal will to dissenting creditors, since the judicial authority is empowered to restrict any non bona fide lawful relevant will (selfregulation of preventive bankruptcy is available only to bona fide participants). If the majority of creditors do not agree on a preventive restructuring plan, it creates a presumption of bad faith of the debtor and the debtor will have the burden of proving its good faith to a judicial authority. The self-elimination of creditors from negotiations should create a presumption of their bad faith, which encourages creditors to provide evidence in defense of their legal position, which will be taken into account by the court when assessing the reasonableness of creditors' vote. Such regulation of preventive restructuring has elements of a bankruptcy legal nature, since creditors, who do not have legal relations with each other, are forced to interact among themselves under the influence of a judicial authority. Thus, this negotiation procedure acquires an adversarial nature. The judicial body can be the guarantor of the reasonableness and economic viability of the preventive restructuring plan and good faith of all parties (bankruptcy elements) only within the framework of the preventive restructuring during the entire procedure. Otherwise, it would be unfair to undermine the creditors' rights and require creditors to take additional obligations. The main disadvantage of such regulation includes significant time spent on this process (the more creditors there are, the more and heterogeneous the assessments will be, each of them will assess the other). If there is doubt about the good faith of the debtor and the effectiveness of the plan, the judicial authority will refrain from the principle of "cross- 
class cram-down". However, the passivity of the judiciary in case of disagreement of the majority of creditors essentially means the support of creditors, so the court must every time find a balance between passive and active behavior.

\subsection{The legal nature of bankruptcy prevention under Russian law}

Russian bankruptcy prevention is defined as measures which are available only before one of the creditors completes an application for declaring the debtor bankrupt in court (Zhukova, Kondrat'eva 2012, 101). According to Article 31 of the Federal law "On Insolvency (Bankruptcy)" No. 127-FZ as of October 26, $2002^{4}$ (hereinafter the Russian Law), it is an ordinary contract between the debtor and the second party (hereafter rescuer) that will pay off all debts of the debtor to all creditors (Tiuleneva 2017, 36). A feature of Article 31 of the Russian Law is that the debtor's solvency is restored, and the debts are fully repaid by the rescuer (Popondopulo 2003, 488). The fact that this institution qualifies only as an ordinary contract provides creditors with the right to dispute it in court during all periods of negotiation, which creates legal instability (Stefanishina, 2018, 309) because it may at any time turn into a traditional insolvency court procedure as each creditor can at any moment initiate bankruptcy proceedings (Tiuleneva 2017, 183). Some authors believe that the consent of the debtor should not be a necessary regulatory requirement (Tiuleneva 2017, 40). According to S. V. Stephanishina, "art. 31 also implies a reduction in the number of employees" (Stefanishina 2018, 312). Employees have homogeneous and unchanging interests both during the prevention of bankruptcy and in an event of initiation of traditional court insolvency proceedings, unlike other creditors whose interests always differ among themselves. The employees only have the following goals: the continuation of labour relations by keeping the debtor, their employer, in the market and the regular issuance of their full salary. Therefore, other creditors are less tied to the debtor, unlike employees, because the fate of the debtor directly affects employees (Mastilovic 2020, 432). The only problem is that the debtor may act in bad faith with the funds received and not use them for their intended purpose - to pay off debts to all creditors. In this case, at the pre-bankruptcy stage, another creditor will appear (a bona fide person who repaid the debt). According to Russian law, procedures of bankruptcy prevention and traditional insolvency proceedings are available at the same stage - the debtor's insolvency. This means that all creditors, together, do not have the right to stop one creditor who wants to initiate traditional bankruptcy proceedings during the negotiation of bankruptcy prevention (thereby making bankruptcy prevention impossible). The opposite also holds true, even if all creditors wanted to rescue the debtor within traditional court rehabilitation insolvency procedures, they cannot stop one "rescuer", who wants to pay off all debts within a bankruptcy prevention according to Art. 31. At the stage of the solvency of the debtor, no creditor has any rights in relation to the debtor. Without a person ready to pay off all the debt according to Art. 31 of the Russian law, it is not allowed by either the judicial authority, any of the creditors, all creditors together, or the debtor independently applying Art. 31, unlike other rehabilitation procedures. As a result, this article is an imperative norm, but it is applied dispositively.

${ }^{4}$ Federal law "On Insolvency (Bankruptcy)" No. 127-FZ. October 26, 2002. Accessed October 19, 2020. http://www.consultant.ru/document/cons_doc_LAW_39331. 
Creditors are always primarily interested in full and instant satisfaction of the entire claims' amount (bankruptcy element), which is guaranteed by Art. 31 of the Russian law. Taking into account that Art. 31 is a once-off legal act (civil law element), it is not typical for bankruptcy regulations since bankruptcy law regulates procedures, but not once-off acts. Article 31 of the Russian bankruptcy law is available only at the stage of insolvency of the debtor, at the same time it has an exclusively contractual-legal law nature, which is applied inter partes, and does not generate any of the traditional bankruptcy legal consequences, such as binding the dissenting minority of creditors.

Why was it necessary to put Art. 31 in the bankruptcy law, considering the civil law characteristics of this article such as voluntariness of applications by counterparties, nondistribution of consequences to non-participating creditors and absence of binding dissenting creditors? Besides, the debtor always had, has and will have the right, within corporate and contractual law, to find such a person ready to pay off debts for him.

The essence of the "insolvency" criterion, under the Russian law regulation, is the identification of the moment when the debtor is incapable to pay off all his debts to all creditors (Art. 2 of the Bankruptcy Law Act of the Russian Federation). A one-time repayment of debtor's debts does not imply the establishment and elimination of the causes of their occurrence, thereby the probability of their recurrence is not excluded and we cannot characterize this institution as a rehabilitation one. Art. 31 does not provide for the obligatory disclosure by the debtor to the creditors that he is in search of a rescuer. Hence, the creditors cannot reliably determine the prospects for further relationships with the debtor. This is justified by the fact that creditors are satisfied with their claims. Therefore, the legislator should allow the debtor at the stage of such an "ability" (solvency) to initiate bankruptcy prevention even without the consent of creditors, if he can convince the judicial authority of such a need. This is because the chance of rehabilitation at the stage of solvency will be certainly higher than at the stage of insolvency within the framework of traditional rehabilitation procedures. The main indicator for the possibility of bankruptcy prevention is not whether the insolvency occurred or not, but whether the financial difficulties are temporary or long-term. If it is temporary, it is necessary to provide the debtor with the opportunity to prevent bankruptcy.

\subsection{The legal nature of bankruptcy prevention: Russian and European law}

Traditional insolvency court procedures do not take into account the interests of the debtor nor the minority of the dissenting creditors and hence they have a smaller circle of persons whose interests it protects compared to both the European and Russian regulations of bankruptcy prevention. Does the basis, on which normative legal collectivity is possible, play a role: the law (requiring the consent of a certain percentage of creditors), the judicial authority (discretionary) or if it is provided to legal persons based on selfregulation (Art. 31 of the Russian Law)? The normative requirement for the consent of the majority of creditors at the European pre-bankruptcy stage is a bankruptcy requirement. Under European law the emergence of legal relations, its implementation and termination have a bankrupt legal nature. Negotiations on bankruptcy prevention under European and Russian regulations have a civil law legal nature and under both Russian and European regulations are conditioned by voluntary debtor's consent, but the disclosure of the debtor itself does not oblige creditors to consent. Therefore, the task of both legislators is 
to stimulate the debtor's initiative. As a general rule, the closer the debtor is to the state of insolvency, the less interested the creditors are in preventing bankruptcy (they prefer to instantly satisfy their claims) and vice versa. The difference is that according to European regulation it is possible to overcome the legal will of the creditor by the court and to bind dissenting creditors with new obligations, while under the Russian regulation, requirements of all creditors are instantly and completely satisfied, and it is impossible to bind dissenting creditors with new obligations.

The consent of the creditors' majority is legally relevant during the European procedure of preventive restructuring only if it is economically reasonable and fair, while in accordance with Art. 31 of the Russian Law the court does not check principles of reasonableness and fairness due to the presence of a "rescuer", who ensures financial resources with the amount, which covers the total debts of the debtor to all his creditors. Such an act by the "rescuer" leads to the final termination of all previously existing legal relations between creditors and the debtor (it automatically abolishes the existing civil rights of creditors' claims against the debtor). The advantage of bankruptcy prevention under Russian regulation over European regulations is the quickness and "completeness of the result". According to the Russian law, all existing debts are paid off immediately in relation to all creditors at the time of the approval of the plan, while under Directive 1023/2019, each creditor is guaranteed partial payment ('best-interest-of-creditors test') at the time of the approval of the plan, but only awarded at the end of the procedure. The Russian bankruptcy law instantly secures the interests of all creditors and the debtor. Directive $1023 / 2019$ also protects the interests of all creditors but not instantly and not completely preconditioned with only the 'best-interest-of-creditors test'.

Insolvency and pre-insolvency procedures can therefore be summed up in collectivities depending on the number of people who are entitled to protection as:

- "normative legal collectivity" - mandatory distribution of consequences to all parties;

- "actual collectivity" - the voluntary consent of all creditors in a particular case;

- "regulatory actual collectivity" - the requirements for voluntary consent of all creditors.

Accordingly, bankruptcy prevention procedures have many more characteristics of collectivity (in terms of the number of persons who receive protection). Consequently, "normative legal collectivity" (mandatory distribution of consequences to all) cannot be the only criteria for defining bankruptcy legal nature, but it is also necessary to take into account collectivity in protecting the interests of all persons. The lack of one of them cannot be considered as the only criterion for determining non-civil law regulations. "Regulatory absolute voluntariness" is mentioned when there is a regulatory requirement to reach the consent of all creditors and the debtor, which is not the case neither in preventive restructuring, nor in traditional insolvency rehabilitation procedures. In these cases, there are adequate requirements to obtain the actual consent of the majority of creditors, to bind dissenting minority of creditors. Undoubtedly, such "regulatory relative voluntariness" (the consent of some creditors was sufficient to extend the legal consequences to all creditors) is always accompanied by "regulatory relative coercion" (the legal will of the consenting majority of creditors is compulsorily extended to some of the dissenting creditors). In the framework of European preventive restructuring, voluntariness is more 
pronounced than in the framework of traditional court insolvency procedures, because in addition to the consent of the majority of creditors, the consent of the debtor is required. Therefore, European regulation is characterized by a higher level of "actual collectivity" in terms of regulatory requirements, while according to Russian regulation, "collectivity" is more pronounced in terms of absolute distribution of positive consequences (only 2 persons participate: the debtor, and second party, which could be also a creditor, and doesn't require the consent of any percentage of creditors, but the claims of all creditors are simultaneously and completely satisfied, which European regulations do not provide). Both preventive restructuring (as a general rule) and traditional bankruptcy procedures provide for the collective spread of consequences to all creditors and the debtor. However, this task is not primarily for pre-bankruptcy regulation, but to collectively ensure that all creditors take measures that will lead to the prevention of bankruptcy according to the same rules and conditions. The collectivity in preventive restructuring ensures the interests of all persons compared to traditional insolvency procedures, where only the interests of the majority of creditors are taken into account. This means that collectivity is both in the mandatory extension of the consequences to all persons and in the protection of the interests of all persons.

The percentage of successful results of preventive restructuring in accordance with Directive 1023/2019 is higher compared to Russian regulations because all creditors jointly share the task of recovering all the debtor's debts, while according to Russian regulations, all obligations fall on one person. According to the civil law regulation, the judicial authority does not have the right to intervene in civil legal relations until one of the parties violates its obligation.

Creditors, according to European preventive restructuring, do not act as one counterparty to the debtor but instead, every creditor has the right to defend its individual interests throughout the entire procedure. In case of the absence of creditors' complaints, the procedure automatically transforms from individual to collective. Within the framework of traditional court insolvency proceedings, at the stage of insolvency of the debtor both under Russian and European legislation, no additional guarantees are provided to creditors. If the bankruptcy legislator guarantees a certain amount of rights to creditors in traditional insolvency proceedings, then the legislator should guarantee the same amount of rights or more (Russian pre-insolvency regulation provides more rights for creditors than European regulation of bankruptcy prevention).

Article 31 of the Russian Law leads to the full repayment of the debtor's debts to all creditors, which creates absolute equality for all creditor, except for the rescuer. The equality of all creditors also lies in the fact that each of them has the right to become the rescuer. Such absolute equality of creditors is impossible in the framework of bankruptcy proceedings, since creditors are divided at the regulatory level into classes. It means that some of them fully satisfy their requirements instead of other creditors. The equality of creditors under the regulation of Directive 1023/2019 is relative and in many respects similar to the equality of creditors in traditional court insolvency proceedings (similarly in accordance with the preamble of Directive 1023/2019 (paragraph 50), creditors are guaranteed the 'best-interest-of-creditors test'). Of course, preventive restructuring does not exclude the possibility of satisfying the full claim, but it is not permitted to receive an amount higher than the amount of the main claim (it means that at the stage of the debtor's solvency, bankruptcy rights are guaranteed despite the fact that the creditor's rights to initiate bank- 
ruptcy proceedings did not yet arise, which indicates bankruptcy legal nature instead of civil.)

\subsection{Bankruptcy prevention: civil, corporate or bankruptcy legal nature}

Within the framework of corporate relations, a company is obliged to periodically transfer financial values (dividends) to other legal persons such as shareholders (Vitrianskii 2010,13). The main task of corporate legal law regulation is obtaining the legally correct distribution of profits (the debtor has the right to do everything that is not prohibited). Within the framework of contract law, the debtor has the right to do what he has agreed with the other party. At the same time within the framework of traditional bankruptcy proceedings, the debtor has the right to do what secures the best-interest of creditors. The regulation of pre-bankruptcy is more similar to regulation of bankruptcy law than the civil law for three reasons: 1) only the rules regulating bankruptcy are appropriate for regulating the prevention of bankruptcy. Civil law regulation cannot restrict the same civil rights in order to guarantee the collective interest of all interested parties;2) the right of the judicial authority to intervene in determining the purpose and conditions of the preventive restructuring plan is not typical for civil law regulation; 3) regulation of prebankruptcy secures "the best-interest-of-creditors-test", which is connected to traditional insolvency procedures. Such a legislative understanding will become more appropriate, since a solvent debtor always had and will have the right to independently rescue itself in order to prevent bankruptcy by the use of corporate and civil legal means. By initiating bankruptcy prevention, the debtor acknowledges that he needs the support of all creditors and without their help he will not overcome the financial difficulties on his own or with the help of only some creditors.

Is it correct to say that an essential feature of insolvency law is the extension of consequences to all creditors, where the enforcement rights of individual creditors will be collectively limited in the interests of all creditors? The approval of a preventive restructuring plan limits the already existing civil rights, thereby automatically changing all legal relations between the debtor and specific creditors (Eidenmüller 2018, 66, 71). Despite the fact that in accordance with Art. 15 of Directive 1023/2019, the effects of preventive restructuring may apply to all creditors whose interests are affected by the plan, the judicial authority is given the right to restrict the application to individual creditors or class only. For example, in France, in the event of the initiation of a "procedure de savegarde", an automatic prohibition is imposed on the initiation of exacting procedures only for creditors - financial institutions; this prohibition does not apply to other creditors. In the United Kingdom, the Scheme of Arrangement does not provide for such a ban at all. All other restrictions apply to creditors only on a voluntary basis (on agreement), in accordance with contractual obligations. Therefore, these institutions are not bankrupt, since they do not imply collective and obligatory cooperation of all persons in the common interest (Westbrook et al. 2010). Russian authors also share this view, Gabriel Shershenevich writes: "measures to prevent bankruptcy proceedings are applied on a voluntary basis between the debtor and all his creditors. Creditors can agree to debt reduction, to replace some obligations with others, but all these agreements do not go beyond the legal contractual agreements, and therefore should not have a special place in bankruptcy legislation" (Shershenevich 2003, 195). Russian academics also share this view. According to Vasilii 
Vitryansky, this is only financial assistance to the debtor, not an insolvency procedure (Vitrianskii, ed. 2000, 38-39). Vladislav Anokhin adheres to the same position (Anokhin 2006, 24). Bankruptcy institutions should provide for binding and collective applications, since ad hoc contractual legal means cannot achieve common goals, due to the fact that each creditor has its own individual and legitimate interest and rights to the debtor. Insolvency law is defined as a collective response to a debtor's default (Westbrook et al. 2010) and finding a balance of interests (De Weijs, Baltjes, 2018, 227), therefore, the outcome in the case of the application of contractual remedies is hardly predictable. Negative consequences will surely spread to everyone. If bankruptcy procedures concern everyone, then bankruptcy prevention should also apply to everyone. Self-regulation is the only way to effectively regulate bankruptcy prevention, because the risk for the result is transferred to creditors. The debtor should have the right to abandon corporate and contractual rights in favour of bankruptcy regulation in order to receive new rights and assume new obligations based on the already existing corporate and contractual rights if the ultimate goal is to prevent bankruptcy. The legal will of creditors and a solvent debtor, who share a goal of preventing bankruptcy, should have the right to predetermine the legal regulation and applicable law: civil or pre-bankruptcy.

\subsection{Legal nature of principles of "voluntariness" and "self-regulation" within pre-insolvency proceedings}

The main feature of the contract, through which its concept is revealed, is the voluntary consent of persons. The agreed free will of the parties to the contract is a necessary requirement of any contract, in its essence. The parties voluntarily decide on the choice of a counterparty, with which they will enter into a legal relationship. If the will of one or both parties has absolutely no meaning for the occurrence legal relationship, then there is no contract (Popondopulo 2009, 139-140, 143). Under Russian law, the debtor's insolvency is a legal condition for both the prevention of bankruptcy and the initiation of traditional court insolvency proceedings. This means that since the legal criteria coincide, the applicable law and selection of procedure depends only on the subsequent discretionary will of the creditors and the debtor. The more the legal criteria for the application of these two procedures coincide, the more the discretionary will of the participants determines the applicable law and thus the result. This does not mean that an input into the law differentiating the criteria for entering solvency and insolvency will make the legal will of creditors and the debtor irrelevant. Hence, it can be concluded that the presence of debtor's insolvency under Russian law is not a criterion for predetermining bankruptcy nor civil law legal nature.

In the context of bankruptcy prevention, the concepts "voluntariness" and "collectivity" are not synonymous (in addition, as part of the preventive restructuring, the court was empowered, as an exception, not to collectively extend the consequences to all creditors). These concepts only interact. Collectivity was identified as an inherent feature of bankruptcy and pre-bankruptcy regulation in the context of "normative legal collectivity" but not in "actual collectivity".

The author recommends introducing a new institution into the law - an "out-of court preventive rehabilitation agreement", the condition for the conclusion of which will be the actual consent of all creditors and the debtor as well as the absence of le- 
gal grounds of bankruptcy (Mastilovich 2020, 143). The consent of all creditors removes the need for judicial intervention, which will distinguish this institution from the rest of the pre-bankruptcy institutions. However, an "out-of court preventive rehabilitation agreement" is quite different from the institutions of preventive restructuring from Directive 1023/2019. In contrast to the "out-of court preventive rehabilitation agreement", the European preventive restructuring procedure can be terminated upon application to the court by even one creditor, if he proves that it violates his rights. Also, in the European preventive restructuring procedure third parties can participate in contrast to the "out-of court preventive rehabilitation agreement" (when it comes to the conclusion of an "out-of court preventive rehabilitation agreement", only those creditors who exist on the day of its conclusion have the right to participate in practice). This suggests that the "out-of court preventive rehabilitation agreement" does not have the nature of civil regulation because the conclusion of civil contracts is not conditioned by the obligatory certain number and certain types of entities, while the "out-of court preventive rehabilitation agreement" can only be concluded by all existing creditors at the time of its conclusion. The voluntary consent of all creditors only "strengthens" the collectivity, but it is not a mandatory characteristic of it.

This institute will be in demand when the number of creditors is small and their interests are homogeneous, and their financial condition is stable. In the context of the current level of development of positive legislation, such an absolute voluntariness (of the debtor and all creditors) and independence and equality of parties (there is no bankruptcy law stipulated for the division of creditors into categories within which creditors' claims are satisfied in a different priority) characterizes contractual legal law regulation. Nevertheless, if, by virtue of regulation, the purposes of the conclusion and the consequences of the institution should apply to all creditors of the same person (the debtor), then such a procedure is more related to bankruptcy law than contractual legal law.

Under European regulation, at the pre-bankruptcy stage of a solvent debtor, the legislator cannot, using objective parameters, regulate the causal relationship between the occurrence of financial difficulties and the prospects for overcoming them (they are internal), and he cannot guarantee the result. Therefore the relationship is more subject to the principle of self-regulation, in contrast to the stage of traditional insolvency procedures, of the insolvency debtor, which is characterized by the principle of imperative legal regulation. This is the reason why risks must be distributed among all creditors and the debtor (the legislator can only determine the purpose and the framework of regulation). Civil regulation cannot ensure the equality of creditors at the pre-bankruptcy stage, since inter partes of the debtor's legal relations with each of the creditors may be in conflict. At the same time, the creditors and the debtor have a common interest - to prevent the debtor's insolvency. Both parties (the debtor and the creditors) pursue the same goal, which is not typical for civil regulation. If the purpose of the procedure takes into account the interests of all persons, then the extension of the will to "dissenting" creditors is not relatively involuntariness. When the interests of all persons are not taken into account (within the framework of traditional bankruptcy proceedings, the interests of the lower classes of creditors are not taken into account), then the principle of relative voluntariness is applicable. The initiation of the bankruptcy prevention procedure under both Russian and European regulations is conditioned by the participants' assessment of the causes of financial difficulties, the prospects for overcoming them and the interests of creditors. 
These two principles are mutually exclusive and opposite. The use of pre-bankruptcy institutions should be more conditioned by the principle of self-regulation (at the stage of the debtor's solvency there is an economic presumption that the debtor will be able to fulfill all his obligations to creditors). At this stage, entrepreneurial activity does not stop, hence, only the debtor and creditors can assess the causes of financial difficulties and prospects and ways to overcome them.

\section{Conclusions}

The legal nature of preventive restructuring depends not only on the legal conditions for entering the procedure, but also on the legal consequences, the level of participation and the influence of creditors, debtor and judicial authority on the procedure, causa finalis of the procedure, compatibility of interests of creditors and debtor, transparency, and level of self-regulation (discretionary freedom of creditors and debtor). It carries more weight in assessing whether it is bankruptcy regulation or contractual regulation compared to the presence of voluntariness or compulsion as a condition for entering into an agreement. Within traditional rehabilitation insolvency procedures, contracts are also concluded, but the clauses from the contracts are applied as lex specialis in relation to bankruptcy law. Such heterogeneous goals can only be ensured by the combined use of both bankruptcy and civil law legal mechanisms. The legal will of the court is always higher than the legal will of private legal entities, but it is worth noting that within the framework of civil law regulation, the judicial authority is involved only in case of violations of obligations in legal relations and civil law is incapable of predicting economic results (only bankrupt law is capable). In addition, bankruptcy law is only capable of guaranteeing all creditors that they will have a common goal and legal consequences, despite the fact that each of them has a different legal relationship with the debtor. Despite all the differences, the legal means of traditional rehabilitation procedure and bankruptcy prevention are similar, since they are implemented using the same types of contracts from civil law. Prebankruptcy rules contain many elements of civil law in order to provide a higher level of self-regulation (self-regulation is a characteristic of civil regulation). One may ask why are traditional rehabilitation insolvency procedures endowed with a bankruptcy law legal nature, while the preventive restructuring rehabilitation with a civil law? The legal nature law is determined not only based on normative law regulations but also on law doctrines. The bankruptcy legal law nature is justified from a normative requirements point of view; the majority of creditors can forcibly extend their will to the dissenting minority of creditors and the debtor (collectivity in the distribution of consequences). It is also necessary to take into account the actual collectivity (the number of persons who actually give consent to carry out a particular procedure). This means that in traditional rehabilitation insolvency procedures, when determining the legal nature, the achievement of the actual consent of all creditors and the debtor should be taken into account (at this stage, the doctrine in any case defines it as bankruptcy). The rights of the debtor and creditors of lower classes are not considered by the judicial authority solely on the grounds that their interests are inferior to the interests of the upper class creditors. Bankruptcy elements in pre-bankruptcy regulation are necessary in order not to allow the privileged creditors according to bankruptcy law to disturb the process of pre-insolvency because they are not interested in taking the risk of participating in bankruptcy prevention like other creditors 
for whom this is the only way to satisfy their claims. However, the privileged creditors, like other creditors, must be guaranteed the "best-interest-of-creditors-test". To overcome this obstacle, it is necessary that the pre-bankruptcy law be endowed with lex specialis in relation to the bankruptcy law. Nevertheless, the most obvious characteristic of civil law regulations remains in the pre-bankruptcy regulation - self-regulation between the debtor and creditors.

\section{References}

Anokhin, Vladislav S. 2006. "Prevention of bankruptcy and an attempt to return the solvency of an insolvent debtor". Khoziaistvo i pravo: priloznenie 1: 1-48. (In Russian)

De Weijs, Rolef, Meren Baltjes. 2018. "Opening the door for the opportunistic use of interim financing: A critical assessment of the eu draft directive on preventive restructuring frameworks" International Insolvency Review 27 (2): 223-254.

Eidenmüller, Horst. 2018. "What is an Insolvency proceeding". American Bankruptcy Law Journal 1: 53-71.

Garašić, Jasnica. 2017. "Najznačajne novine Stečajnog zakona iz 2015. godine”. Zbornik Pravnog fakulteta Sveučilišta Rijeka 1 (38): 131-184.

Kutufà, Ilaria. 2018. "The Financial distress of individual debtors: Points for a de jure condendo reflection from a comparatie perspective". European Journal of Legal Studies 11 (1): 67-96.

Mastilovic, Larisa. 2020. "La tutela europea dei diritti dei lavoratori nelle procedure di ristrutturazione preventiva in materia fallimentare e il confronto con la disciplina dell'insolvenza in Croazia, Serbia e Russia". Il diritto del mercato del lavoro 2: 425-443.

Mastilovich, Larisa. 2020. "Out-of court preventive rehabilitation agreement as a method for preventing the occurrence of legal signs of bankruptcy". Vestnik Sankt-Peterburgskogo universiteta. Pravo 1: 140-153. https://doi.org/10.21638/spbu14.2020.110.

Popondopulo, Vladimir F. 2003. Commentary on the Federal Law on Insolvency (Bankruptcy). Moscow, Omega Publ. (In Russian)

Popondopulo, Vladimir F. 2009. “Contract as a means of private law regulation”. Pravovedenie. Izvestiia vysshikh uchebnykh zavedenii 4 (285): 137-151. (In Russian)

Shershenevich, Gabriel F. 2003. Commercial Law Course: Commercial Process. Concorsual process. Moscow, Statut Publ. (In Russian)

Stefanishina, Svetlana V. 2018. "The status of third parties in the implementation of their pre-trial reorganization in bankruptcy”. Vestnik Kostromskogo gosudarstvennogo universiteta 2 (24): 309-312.

Tiuleneva, Tat'iana A. 2017. Accounting and analysis of bankruptcies: a tutorial. Kemerevo, Kuzbasskii gosudarstvennyi tekhnicheskii universitet imeni T. F. Gorbacheva Publ. (In Russian)

Tollenaar, Nicolaes W. A. 2017. "The European Commission's Proposal for a Directive on Preventive Restructuring Proceedings". Insolvency Intelligence 5 (30): 65-81.

Vitrianskii, Vasilii V. 2010. "Some basic provisions of the concept of development of civil legislation of the Russian Federation on obligations". Zhurnal rossiiskogo prava 1: 13-25.

Vitrianskii, Vasilii V., ed. 2000. Commentary on the Federal Law on Insolvency (Bankruptcy). Moscow, Statut Publ. (In Russian)

Westbrook, Jay Lawrence, Charles D. Booth, Christoph G. Paulus, Harry Rayak. 2010. A Global View of business insolvency System. Washington, DC, World Bank.

Zhukova, Tat'iana M., Kseniia S. Kondrat'eva. 2012. "Improving the order of legal regulation of sanctions as a way to ensure the financial stability of the debtor". Vestnik Permskogo universiteta. Iuridicheskie nauki 3 (17): 101-106.

Received: December 2, 2020 Accepted: March 15, 2021

Author's information:

Larisa Mastilovich — Junior Research Fellow; larisa.mastilovic@mail.ru 